\title{
SOIL COMPOSITION AND NUTRITIONAL STATUS OF APPLE AS AFFECTED BY LONG-TERM APPLICATION OF GYPSUM(1)
}

\author{
Gilberto Nava ${ }^{(2)}$, Paulo Roberto Ernani( ${ }^{(3)}$, Alessandra Aparecida de \\ Sá(4) \& Adilson José Pereira( ${ }^{(2)}$
}

\begin{abstract}
SUMMARY
Gypsum does not affect the soil negative charges and maintains sulfate in the soil solution, making it one of the cheapest products to increase Ca activity in soil solution, especially in the deeper soil layers. Higher Ca levels in the soil solution can increase the uptake of this nutrient by apple trees, reducing the risk of physiological disorders caused by Ca deficiency. This study assessed the effect of long-term gypsum application on some soil properties and on the chemical composition of leaves and fruits of an apple cultivar susceptible to fruit disorders associated with low Ca. The experiment was conducted in São Joaquim, in the South of Brazil, from 2001 to 2009. Gypsum rates of 0, 1.0, 2.0 and $3.0 \mathrm{t} \mathrm{ha}^{-1}$ were annually broadcast over the soil surface, without incorporation, in an apple orchard with cultivar 'Catarina', planted in 1997. Gypsum application over eight consecutive years had no effect on soil exchangeable $\mathrm{K}$ and $\mathrm{Al}$ to a depth of $80 \mathrm{~cm}$, but increased exchangeable $\mathrm{Ca}$ in the sampled layers $(0-10,10-20$, 40-60 and 60-80 cm), while exchangeable Mg decreased only in the surface layer $(0-20 \mathrm{~cm})$. Gypsum did not affect the concentration of any nutrient in the fruits, including $\mathrm{Ca}$. The same was verified in the leaves, except for $\mathrm{Mg}$ which decreased with increased gypsum rate. Despite increasing the availability of $\mathrm{Ca}$ in the soil profile to a depth of $80 \mathrm{~cm}$, gypsum was not effective to increase the Ca content in leaves and fruits of an apple cultivar susceptible to Ca deficiency grown in an appropriately limed soil.
\end{abstract}

Index terms: downward movement, cations, nutritional status, calcium.

(1) Received for publication in December 15, 2010 and approved in October 13, 2011.

(2) Research Scientist at São Joaquim Experimental Station, Epagri. Rua João Araujo Lima 102, CEP 88600-000 São Joaquim (SC). E-mails: nava@epagri.sc.gov.br; pereira@epagri.sc.gov.br

(3) Professor at the department of Soil Management at Santa Catarina State University - UDESC. C.P. 281, CEP 88520-000 Lages (SC). E-mail: prernani@cav.udesc.br

(4) Postgraduate student - Master in Soil management, UDESC. E-mail: lelezinha_sa@yahoo.com.br 


\title{
RESUMO: COMPOSIÇÃO DO SOLO E ESTADO NUTRICIONAL DA MA- CIEIRA ALTERADOS PELA ADIÇÃO DE GESSO
}

\begin{abstract}
O gesso agrícola não altera as cargas negativas do solo e mantém o sulfato na solução, razão pela qual é uma das fontes mais baratas para aumentar a atividade do Ca, principalmente nas camadas mais profundas do solo. O maior teor de Ca na solução do solo pode aumentar a absorção desse nutriente pela macieira, reduzindo o risco de distúrbios fisiológicos causados pela deficiência de Ca. Oobjetivo deste trabalho foi avaliar a influência da aplicação de gesso sobre alguns atributos químicos do solo e sobre a composição química de folhas e frutos de uma cultivar de macieira sensivel à deficiência de Ca. O experimento foi conduzido durante o período de 2001 a 2009, em São Joaquim, SC, num pomar de macieira implantado em 1997 com a cultivar Catarina. Os tratamentos consistiram de aplicações anuais de gesso agrícola nas doses de 0; 1,0; 2,0; e 3,0 tha-1 sobre a superfície do solo, sem incorporação. A aplicação de gesso por oito anos consecutivos na superfície do solo não influenciou os teores trocáveis de K, tampouco de Al. Os teores de Ca trocável foram incrementados pelas doses de gesso nas diferentes camadas de solo amostradas (0-10, 10-20, 40-60 e 60-80 cm de profundidade), enquanto os de Mg diminuíram somente nas camadas superficiais $(0-20 \mathrm{~cm})$. A adição de gesso não alterou a concentração de Ca e dos demais nutrientes nos frutos; com exceção do Mg, que teve suas concentrações diminuidas com as doses de gesso. Embora o gesso agrícola tenha aumentado os teores trocáveis de Ca até $80 \mathrm{~cm}$ de profundidade, ele não foi eficiente em aumentar as concentrações de Ca nas folhas e nos frutos de uma cultivar de macieira sensivel à deficiência de Ca quando cultivada em solo adequadamente calcariado.
\end{abstract}

Termos de indexação: movimento descendente, cátions, estado nutricional, cálcio.

\section{INTRODUCTION}

Limestone application is the easiest and cheapest way to increase the level of $\mathrm{Ca}$ in the soil. The $\mathrm{Ca}$ content of commercial dolomitic limes varies from 15 to $40 \%$. Besides supplying both $\mathrm{Ca}$ and $\mathrm{Mg}$ to the soil, liming eliminates the toxic effect of $\mathrm{Al}$ and $\mathrm{Mn}$, increasing soil $\mathrm{pH}$ and cation exchange capacity (CEC). Thus, in variable charge soils, most $\mathrm{Ca}$ and $\mathrm{Mg}$ added by lime is electrostatically adsorbed on the charges generated, since most anions added by liming do not remain in the soil solution. As a consequence, the vertical mobility of $\mathrm{Ca}$ in the soil after liming is restricted to the layers where lime is incorporated (Ernani et al., 2001).

Agricultural gypsum $\left(\mathrm{CaSO}_{4} \cdot 2 \mathrm{H}_{2} \mathrm{O}\right)$ is a byproduct of the phosphoric acid industry. Since gypsum contains $17-20 \%$ of $\mathrm{Ca}$ and $14-17 \%$ of $\mathrm{S}$, it can be used to supply both elements to the plants. In addition, gypsum can ameliorate some physical and chemical soil properties, e.g., improve root growth in the subsoil of highly acidic soils with low Ca (Pavan, 1987; Carvalho \& Raij, 1997), reduce surface crusting of soils with high clay content and decrease the resistance of root penetration in compacted soil layers (Sumner et al., 1986). Furthermore, it is well-known that gypsum application enhances root growth in soils containing toxic $\mathrm{Al}$ levels, as a result of reduced $\mathrm{Al}$ activity in the soil solution (Ritchey et al., 1982).

Unlike lime, gypsum does not raise the soil $\mathrm{pH}$ and therefore not increase cation exchange capacity (Ernani et al., 2001). As a consequence, most Ca atoms from gypsum remain in the soil solution (Ernani \& Barber 1993; Ernani et al., 2001). In addition, since the applied sulfate is not specifically adsorbed by the soil solid constituents, Ca mobility in the soil profile is high after applying this salt (Ernani, 1986; Ernani et al., 2001). Accelerated leaching of $\mathrm{Mg}$ (Rosolem \& Machado, 1984; Caires et al., 2003, 2006; Ernani et al., 2006) and K (Rosolem \& Machado, 1984; Ernani et al., 2006) are some of the drawbacks of large gypsum applications to soils.

Calcium is the most important nutrient for apple quality and storage life. When $\mathrm{Ca}$ is not adequately supplied by the soil or when no Ca sprays are applied during fruit growth and cell enlargement, fruits often have some physiological disorders such as bitter pit, cork spot and lenticel blotch pit, which make them unmarketable. The occurrence of such dysfunctions varies among seasons (Ernani et al., 2008) according to the climate conditions and fruit chemical composition (Amarante et al., 2011).

Calcium absorbed from the soil by the apple trees reaches the fruits via xylem flow within a 
short period, during cell division, which occurs up to approximately 40 days after full flowering (Amarante et al., 2006). Thereafter, the Ca flux passes basically through the phloem, a very slow pathway. In addition, the water and nutrient transport to the xylem via apoplastic transport becomes difficult as roots age. Then, to reach the xylem, transport must pass through the symplast. However, Ca cannot follow this pathway because its concentration in the cell cytoplasm must stay low (Taiz \& Zeiger, 2008). As a result, the Ca concentration in the fruits becomes diluted as they enlarge, creating favorable conditions for the development of physiological disorders.

Most efforts of apple breeding programs around the world have focused on the development of disease-resistant varieties. Recently, Brazilian researchers (Camilo \& Denardi 2002) developed a scab-resistant apple cultivar ('Catarina'). Unfortunately, this cultivar is extremely susceptible to the incidence of bitter pit, which has restricted its use on new plantations.

Many Brazilian growers apply gypsum to apple orchards in order to enhance Ca uptake by fruits and, thus, to increase fruit storage life without any research support. However, many questions remain unanswered about the efficacy of this practice, especially for apple orchards in Brazil, most commonly located upon highly buffered acid soils of predominantly variable charge. This study was conducted with the purpose of assessing soil and plant chemical modifications caused by longterm gypsum rates broadcast on the soil surface of an apple orchard in Southern Brazil, to validate or not its recommendation.

\section{MATERIALS AND METHODS}

The experiment was carried out in an apple orchard in São Joaquim, in southern Brazil $\left(28^{\circ} 17^{\prime} 25^{\prime}\right.$ ' S, 49 $\left.9^{\circ} 56^{\prime} 56^{\prime \prime} \mathrm{W}\right)$, from August 2001 to March 2009. The climate of the region is characterized as humid subtropical, without dry season, with annual mean temperature and rainfall of $13.5^{\circ} \mathrm{C}$ and $1,700 \mathrm{~mm}$, respectively. According to the Köppen classification, the climate is Cfb. Trees of the 'Catarina' cultivar, grafted on Marubakaido rootstock, were planted in 1997, at a density of 883 plants ha-1 $(6 \times 2 \mathrm{~m})$ on a Humic Haplumbrept.

Three months before planting, dolomitic lime was broadcast on the soil surface and incorporated into the $0-30 \mathrm{~cm}$ layer in an amount required to raise water $\mathrm{pH}$ to 6.5. Total rates of $\mathrm{P}$ and $\mathrm{K}$ fertilizer $\left(240 \mathrm{~kg} \mathrm{ha}^{-1}\right.$ of $\mathrm{P}_{2} \mathrm{O}_{5}$ and $120 \mathrm{~kg} \mathrm{ha}^{-1}$ of $\mathrm{K}_{2} \mathrm{O}$ ) was broadcast one week before planting at rates recommended by the official research and extension services (CQFSRS/SC, 2004). Soil samples collected from the $0-20 \mathrm{~cm}$ layer just before treatment application (four years after addition of dolomitic lime and fertilizers) presented $\mathrm{pH}=6.4 ; \mathrm{Al}^{3+}=0 ; \mathrm{P}$ (Mehlich-1) $=19 \mathrm{mg} \mathrm{dm}{ }^{-3} ; \mathrm{K}^{+}=$ $5.2 \mathrm{de} \mathrm{mmol}_{\mathrm{c}} \mathrm{dm}^{-3} ; \mathrm{Ca}^{2+}=103 \mathrm{mmol}_{\mathrm{c}} \mathrm{dm}^{-3} ; \mathrm{Mg}^{2+}=$ $54 \mathrm{mmol}_{\mathrm{c}} \mathrm{dm}^{-3}$; organic matter $=43 \mathrm{~g} \mathrm{dm}^{-3}$; clay $=$ $450 \mathrm{~g} \mathrm{dm}^{-3}, 1.8 \%$ of crystalline $\mathrm{Fe}_{2} \mathrm{O}_{3}$ extracted by citrate-bicarbonate-dithionite (CBD), 0.79 of $\mathrm{Fe}_{2} \mathrm{O}_{3}$ bonded to the organic matter, extracted by sodium pyrophosphate, $0.29 \%$ of morphous $\mathrm{Fe}_{2} \mathrm{O}_{3}$ extracted by ammonium oxalate, and CEC of $190 \mathrm{mmol}_{\mathrm{c}} \mathrm{dm}^{-3}$. The soil is derived from rhyodacite, where kaolinite is the predominant clay mineral, followed by some $2: 1$ clay minerals with polymers of hydroxy- $\mathrm{Al}$ in the interlayers.

Treatments consisted of annual additions, during eight consecutive years, of gypsum at rates of $0,1.0$, 2.0 and $3.0 \mathrm{t} \mathrm{ha}^{-1}$. Gypsum contained $170 \mathrm{~g} \mathrm{~kg}^{-1} \mathrm{Ca}$ and $20 \%$ moisture. It was always broadcast by hand in the winter (July-August) over the whole soil surface, including inter-rows, without incorporation. These rates were determined in view of the solubility of gypsum and the amount of rain in the study region. The four replications of each treatment were arranged in a randomized complete block design. Each experimental unit consisted of five trees within a row, but only the central three trees were used for determinations. The experimental area was treated with all management practices of the commercial orchard, including insecticide and fungicide application, winter and summer pruning and hand thinning. Phosphorus was not applied after planting and $\mathrm{K}$ was annually applied, over the soil surface, at $110 \mathrm{~kg} \mathrm{ha}^{-1} \mathrm{~K}_{2} \mathrm{O}$, as $\mathrm{KCl}$.

The first fruits were analyzed in the 2002/2003 growing season. Each sample consisted of 24 fruits per plot (eight fruits per plant), picked 15 days before commercial harvest. Fruits were washed in the laboratory with distilled water before analysis. To assess the fruit mineral composition $(\mathrm{N}, \mathrm{P}, \mathrm{K}$, $\mathrm{Ca}$ and $\mathrm{Mg}$ ), two longitudinal slices were obtained from each fruit, including the peel. These parts were blended, and approximately $5.0 \mathrm{~g}$ of the slurry was wet-digested with $5 \mathrm{~mL} \mathrm{H} \mathrm{H}_{2} \mathrm{O}_{2}+3 \mathrm{~mL} \mathrm{H}_{2} \mathrm{SO}_{4}$, at $350{ }^{\circ} \mathrm{C}$. Potassium was determined by flame emission spectroscopy, $\mathrm{N}$ by steam distillation in semi-micro Kjeldahl equipment, $\mathrm{Ca}$ and $\mathrm{Mg}$ by atomic absorption spectroscopy and $\mathrm{P}$ by vanadatemolybdate reagents, according to Malavolta et al. (1997).

Composite samples of 45 leaves from the midshoot of the current year's growth from each plot were collected at the end of January of each year (except in the growing season 2005/2006), approximately 120 days after full flowering. The 
leaves were washed with detergent, rinsed with distilled water and oven-dried to constant weight at $65{ }^{\circ} \mathrm{C}$. Subsequently, they were ground and samples of $0.500 \mathrm{~g}$ were wet-digested using nitro-perchloric acids, at $190^{\circ} \mathrm{C}$. The leaf contents of $\mathrm{N}, \mathrm{P}, \mathrm{K}, \mathrm{Ca}, \mathrm{Mg}$, $\mathrm{Cu}, \mathrm{Fe}, \mathrm{Mn}, \mathrm{Zn}$, and $\mathrm{B}$ were quantified as proposed by Freire (1998).

Soil samples were collected only at the end of the experiment, in April 2009, before fruit harvest. Six soil cores were taken from each experimental unit (layers 0-10, 10-20, 20-40, 40-60 and 60-80 cm), air-dried, ground and sieved $(2 \mathrm{~mm})$. They were analyzed for $\mathrm{pH}$ and exchangeable $\mathrm{Ca}, \mathrm{Mg}, \mathrm{K}$ and Al, according to Embrapa (1997).

Results were submitted to analysis of variance (ANOVA) using the Statistical Analysis System (SAS, Cary NC). When there was significance for gypsum rates $(p \leq 0.05)$, regression analysis was performed.

\section{RESULTS AND DISCUSSION}

\section{Effects on soil exchangeable cations}

Exchangeable Ca increased linearly in all soil layers with increasing rate of gypsum broadcast over the soil surface, except for the $20-40 \mathrm{~cm}$ layer (Figure 1; Table 1). In the first layer evaluated (0-10 cm), exchangeable $\mathrm{Ca}$ increased from $105 \mathrm{mmol}_{\mathrm{c}} \mathrm{dm}^{-3}$, of the control (without gypsum), to $147 \mathrm{mmol}_{\mathrm{c}} \mathrm{dm}^{-3}$ in the treatment receiving $3.0 \mathrm{t} \mathrm{ha}^{-1}$ of gypsum annually for eight consecutive years

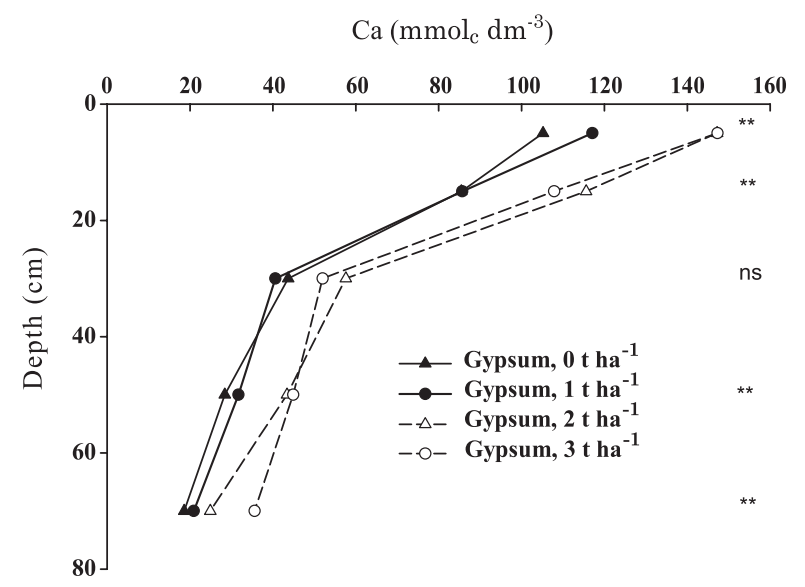

Figure 1. Values of exchangeable $\mathrm{Ca}$ in the soil profile as extracted in $1 \mathrm{~mol} \mathrm{~L}^{-1} \mathrm{KCl}$ after broadcasting annual gypsum rates, from 2001 to 2009 (mean of four replications). **, ns: Significant by linear regression analysis $(p \leq 0.01)$ or non significant, respectively.
Table 1. Regression equations with significant coefficients of determination $(p \leq 0.01)$ between exchangeable $\mathrm{Ca}$ and $\mathrm{Mg}$ in the soil $(\hat{\mathrm{y}})$, for different depths, and annual gypsum rates $(x)$, broadcast on the soil surface from 2001 to 2009

\begin{tabular}{cccc}
\hline$\hat{y}$ & Depth & Equation & $\mathbf{R}^{2}$ \\
\hline $\mathrm{mmol}_{\mathrm{c}} \mathrm{dm}^{-3}$ & $\mathrm{~cm}$ & & \\
$\mathrm{Ca}$ & $0-10$ & $\hat{\mathrm{y}}=105.6+15.6 \mathrm{x}$ & $0.89^{* *}$ \\
& $10-20$ & $\hat{\mathrm{y}}=81.5+11.5 \mathrm{x}$ & $0.67^{* *}$ \\
& $40-60$ & $\hat{\mathrm{y}}=27.7+6.2 \mathrm{x}$ & $0.93^{* *}$ \\
& $60-80$ & $\hat{\mathrm{y}}=17.2+5.2 \mathrm{x}$ & $0.89^{* *}$ \\
& & & \\
$\mathrm{Mg}$ & $0-10$ & $\hat{\mathrm{y}}=59.2-11.8 \mathrm{x}$ & $0.98^{* *}$ \\
& $10-20$ & $\hat{\mathrm{y}}=59.8-8.20 \mathrm{x}$ & $0.95^{* *}$ \\
\hline
\end{tabular}

(Figure 1). In the 10-20 cm layer, $\mathrm{Ca}^{2+}$ increased from 85 to $116 \mathrm{mmol}_{\mathrm{c}} \mathrm{dm}^{-3}$ for the same treatments. Considering the average of these two layers, the concentration of $\mathrm{Ca}^{2+}$ increased by approximately $1.5 \mathrm{mmol}_{\mathrm{c}} \mathrm{dm}^{-3}$ per ton of gypsum applied. The rapid downward movement of $\mathrm{Ca}$ in the soil profile after gypsum application has been extensively described (Ernani, 1986; Caires et al., 1999, 2003; Blum et al., 2011) as a result of the great increase in Ca concentration in the soil solution (Ernani \& Barber, 1993). Because most applied Ca remains associated with sulfate in solution, it is subject to translocation in the soil profile as $\mathrm{CaSO}_{4}{ }^{0}$ (Pavan et al., 1984). Ernani et al. (2001) compared the ability of gypsum and calcium carbonate to improve the Ca content in the subsoil of a Haplumbrept and verified that the vertical mobility of Ca from gypsum was 24 times greater than that from carbonate.

Exchangeable $\mathrm{Mg}$ decreased only in the two surface layers (0-10 and 10-20 cm) (Figure 2; Table 1). The absence of $\mathrm{Mg}$ leaching from the deep layers is probably due to the high CEC of the soil used in our study, which allows electrostatic adsorption of large amounts of this nutrient in the soil. Vertical mobility of $\mathrm{Mg}$ following gypsum application has often been observed in sandy soils (Ernani, 1986; Syed-Omar \& Sumner, 1991). The mobility of the ion pair $\mathrm{MgSO}^{0}$ has been the main cause of the $\mathrm{Mg}$ movement in the soil profile (Zambrosi et al., 2007). The results of this study also show some vertical mobility of $\mathrm{Mg}$, which can however not be considered as leaching since this nutrient still remains in the layers of the apple roots.

Since the $\mathrm{K}$ concentration in the soil solution is lower than of $\mathrm{Ca}$ and $\mathrm{Mg}$, gypsum application had no effect on exchangeable $\mathrm{K}$, regardless of 


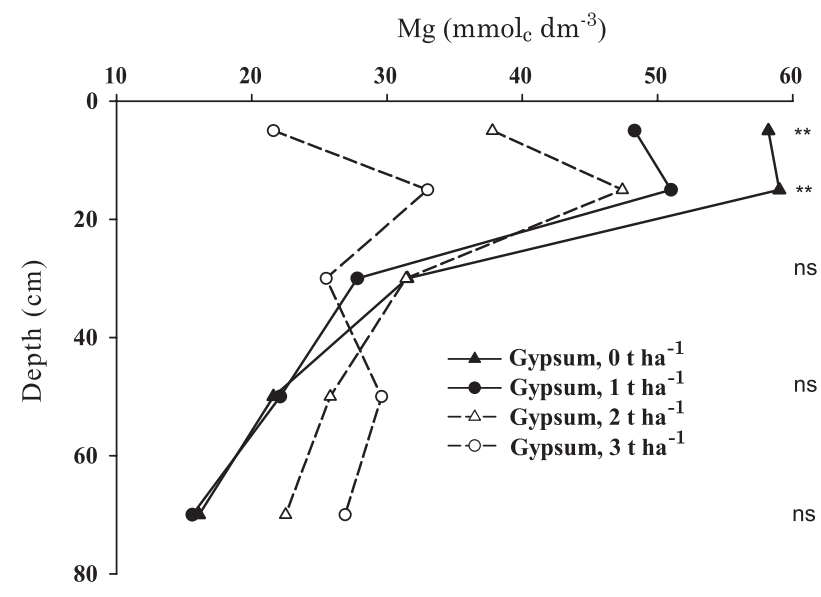

Figure 2. Values of exchangeable $\mathrm{Mg}$ in the soil profile as extracted in $1 \mathrm{~mol} \mathrm{~L}^{-1} \mathrm{KCl}$ after broadcasting annual gypsum rates from 2001 to 2009 (mean of four replications). **, ns: Significant by linear regression analysis $(p \leq 0.01)$ or non significant, respectively.

soil depth (Table 2). Thus, exchangeable $\mathrm{K}$ varied only between soil layers, as a consequence of $\mathrm{K}$ application to the soil surface over time. In Brazil, apple orchards are located in the Southern States, planted mostly on highly buffered soils, as that of this study. Therefore, the risk of $\mathrm{K}$ leaching from this type of soils, even after addition of moderate to high gypsum rates, is relatively low (Ernani, 1986; Suzuki et al., 1992).

Gypsum application had no effect either on exchangeable $\mathrm{Al}$ in the deep layers, where this element was present. In the two surface layers (0-10 and 10-20 cm), soil $\mathrm{pH}$ was higher than 6.0 (Table 2) and, as consequence, no extractable $\mathrm{Al}$ was measured. Al leaching after gypsum application is normally negligible, since the amount of Al displaced from the negative charges by $\mathrm{Ca}$ addition is low (Pavan et al., 1982; Ernani et al., 2001) because Al is electrostatically adsorbed with high energy due to its valence.

\section{Effects on the chemical composition of leaves}

Except for Mg, gypsum application to the soil for eight consecutive years had no effect on the concentration of any nutrient in the apple leaves, regardless of the rate and growing season (Table 3). Although $\mathrm{Mg}$ was not leached from any layers occupied by apple roots, the decrease verified in the two surface layers (0-10 and 10-20 cm), as also observed by Caires et al. (1999, 2003), was enough to decrease its uptake by the plants in three out of six seasons (2004-2005, 2007-2008 and 2008-2009). However, even in these seasons, $\mathrm{Mg}$ leaf concentrations was higher than $1.5 \mathrm{~g} \mathrm{~kg}^{-1}$, value considered adequate for apple trees (Suzuki \& Basso, 2002).
Surprisingly, the Ca leaf concentration was not increased by gypsum application to the soil (Table 3). Absence of changes in Ca leaf concentrations after gypsum application probably reflect the high values of exchangeable $\mathrm{Ca}$ existing in the soil $\left(103 \mathrm{mmol}_{\mathrm{c}} \mathrm{dm}^{-3}\right)$, as a result of previous liming. Since apple roots translocate $\mathrm{Ca}$ to the fruits only during the beginning of fruit formation, an increase in $\mathrm{Ca}$ availability in the soil did not result in increased Ca levels in the fruits. The concentration of $\mathrm{Ca}$ in the leaves remained, in most years, below the normal range for this species (Suzuki \& Basso, 2002), which varies from 11 to $15 \mathrm{~g} \mathrm{~kg}^{-1}$. This shows the importance of supplying $\mathrm{Ca}$ to apple fruits through sprays, because even with addition of $3.0 \mathrm{t} \mathrm{ha}^{-1} \mathrm{yr}^{-1}$ of gypsum, the concentration of $\mathrm{Ca}$ in the leaves remained, in most years, below the normal range for this species. This also reinforces the high susceptibility of the Catarina cultivar to develop physiological disorders related to insufficient Ca levels (Camilo \& Denardi, 2002). The leaf concentrations of all other nutrients evaluated

Table 2. Soil $\mathrm{pH}$ and exchangeable values of $\mathrm{K}$ and $\mathrm{Al}$ at different soil depths after broadcasting annual gypsum rates, from 2001 to 2009

\begin{tabular}{|c|c|c|c|c|}
\hline Depth & Gypsum & $\mathrm{pH}-\mathrm{H}_{2} \mathrm{O}$ & $\mathbf{K}^{+}$ & $\mathrm{Al}^{3+}$ \\
\hline $\mathrm{cm}$ & \multicolumn{2}{|l|}{$\mathrm{t} \mathrm{ha}^{-1}$} & \multicolumn{2}{|c|}{$-\mathrm{mmol}_{\mathrm{c}} \mathrm{dm}^{-3}$} \\
\hline \multirow[t]{6}{*}{$0-10$} & 0 & 6.3 & 9.1 & - \\
\hline & 1.0 & 6.4 & 8.6 & - \\
\hline & 2.0 & 6.6 & 9.8 & - \\
\hline & 3.0 & 6.4 & 9.2 & - \\
\hline & $\operatorname{Effect}^{(1)}$ & $\mathrm{ns}$ & $\mathrm{ns}$ & - \\
\hline & CV (\%) & 3.10 & 19.5 & - \\
\hline \multirow[t]{5}{*}{$0-20$} & $\begin{array}{l}0 \\
1.0\end{array}$ & $\begin{array}{l}6.4 \\
6.1\end{array}$ & $\begin{array}{l}4.2 \\
3.7\end{array}$ & - \\
\hline & 2.0 & 6.3 & 5.2 & - \\
\hline & 3.0 & 6.1 & 4.3 & - \\
\hline & Effect $^{(1)}$ & ns & $\mathrm{ns}$ & - \\
\hline & CV (\%) & 1.97 & 14.2 & - \\
\hline \multirow[t]{5}{*}{$20-40$} & $\begin{array}{l}0 \\
1.0\end{array}$ & $\begin{array}{l}5.3 \\
5.2\end{array}$ & 2.5 & 8 \\
\hline & 2.0 & 5.2 & 2.3 & 9 \\
\hline & 3.0 & 5.1 & 2.4 & 11 \\
\hline & Effect $^{(1)}$ & $\mathrm{ns}$ & $\mathrm{ns}$ & $\mathrm{ns}$ \\
\hline & CV (\%) & 3.75 & 13.8 & 42.3 \\
\hline \multirow[t]{5}{*}{$40-60$} & $\begin{array}{l}0 \\
1.0\end{array}$ & $\begin{array}{l}5.1 \\
5.0\end{array}$ & $\begin{array}{l}2.0 \\
1.8\end{array}$ & $\begin{array}{l}21 \\
22\end{array}$ \\
\hline & 2.0 & 4.9 & 1.9 & 29 \\
\hline & 3.0 & 4.9 & 2.1 & 21 \\
\hline & Effect ${ }^{(1)}$ & $\mathrm{ns}$ & $\mathrm{ns}$ & ns \\
\hline & CV (\%) & 2.3 & 12.9 & 49.0 \\
\hline \multirow[t]{5}{*}{$60-80$} & $\begin{array}{l}0 \\
1.0\end{array}$ & $\begin{array}{l}5.1 \\
5.1\end{array}$ & $\begin{array}{l}2.0 \\
1.9\end{array}$ & $\begin{array}{l}46 \\
48\end{array}$ \\
\hline & 2.0 & 5.0 & 2.4 & 26 \\
\hline & 3.0 & 4.9 & 2.2 & 34 \\
\hline & Effect $^{(1)}$ & $\mathrm{ns}$ & $\mathrm{ns}$ & $\mathrm{ns}$ \\
\hline & CV (\%) & 1.7 & 34.1 & 28.8 \\
\hline
\end{tabular}

(1) ns: effect of gypsum application rate non significant by polynomial regression $(\mathrm{p} \leq 0.05)$. 
Table 3. Concentrations of N, P, K, Ca, Mg, Fe, Mn, Zn, and B in apple leaves, as affected by annual rates of gypsum applications broadcast on the soil surface, from 2001 to 2009

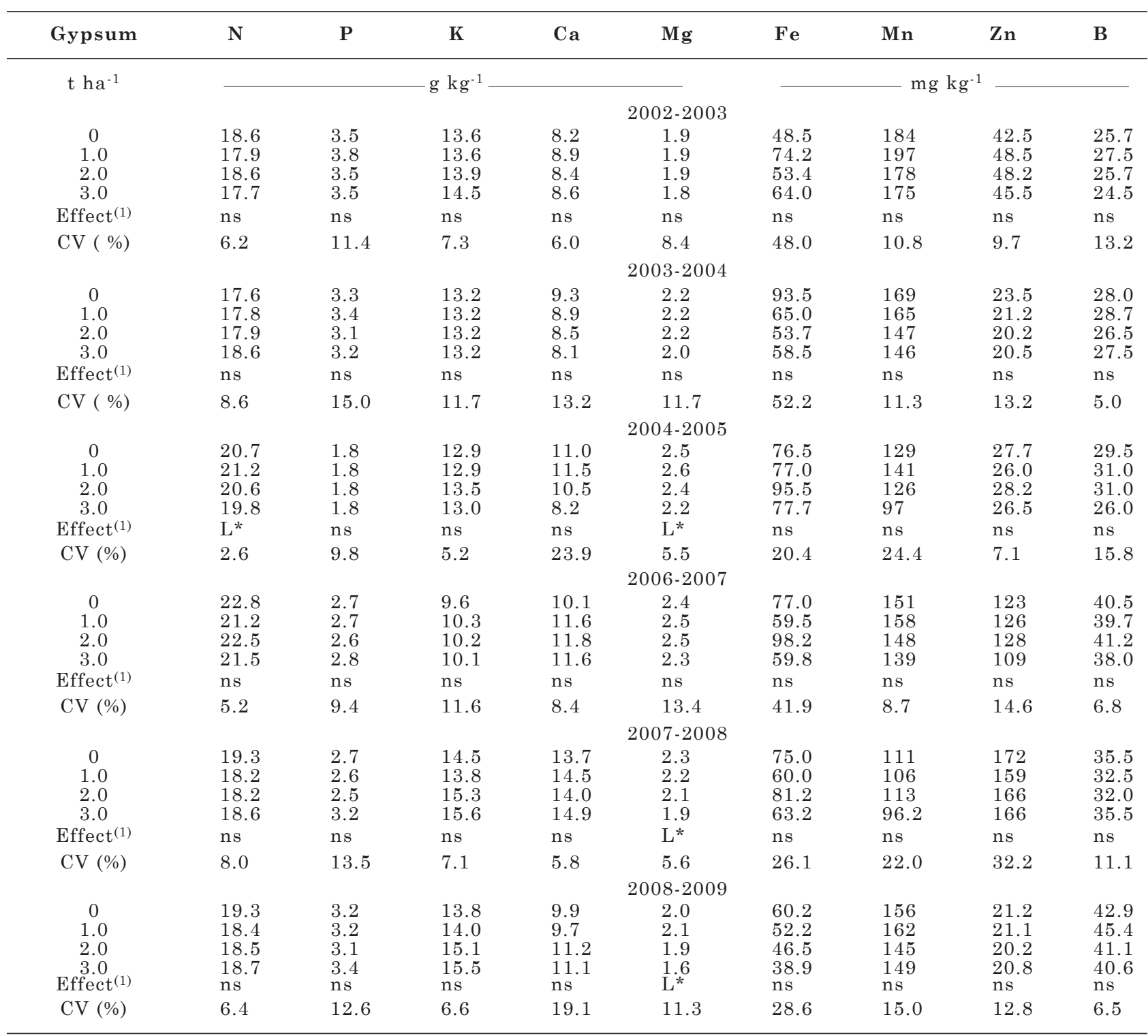

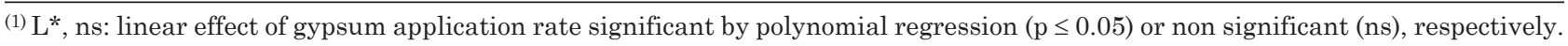

in this study was not affected either by gypsum application to the soil (Table 3).

\section{Effect on the chemical composition of fruits}

Gypsum application had no effect on any nutrient in the apple fruits, independently of rate and growing season (Table 4). Except for the 20082009 growing season, the Ca fruit concentration was always below $40 \mathrm{mg} \mathrm{kg}^{-1}$, which is considered the lower Ca sufficiency threshold for apple fruit. In addition, ratios of N/Ca and of $\mathrm{K} / \mathrm{Ca}$ were higher than 10:1 and 30:1, respectively, in most seasons, indicating high susceptibility to $\mathrm{Ca}$ insufficiency during fruit storage (Nava \& Dechen, 2009). Fruit yield was evaluated in only three growing seasons (data not shown). Since yield was not affected by any treatment, these measurements were discontinued.

The results of nutrient concentration in the fruits corroborate those observed in the leaves in this study, but are in disagreement with findings of other studies after gypsum application in apple orchards (Pavan, 1987; Webster, 1990; Suzuki et al., 1992). Webster (1990) applied gypsum to the surface of a coarse textured soil for six years and observed increased $\mathrm{Ca} / \mathrm{Mg}$ ratio in apple fruits. Suzuki et al. (1992) and Pavan (1987) also found benefits in $\mathrm{Ca}$ dynamics in the apple fruits after gypsum application to Brazilian soils. The cultivar used in 
Table 4. Concentrations of N, P, K, Ca, and $\mathrm{Mg}$ in the fruit flesh and some ratios between them as affected by annual rates of gypsum applications broadcast on the soil surface, from 2001 to 2009

\begin{tabular}{|c|c|c|c|c|c|c|c|c|}
\hline Gypsum & $\mathbf{N}$ & $\mathbf{P}$ & $\mathbf{K}$ & $\mathbf{C a}$ & Mg & N/Ca & $\mathbf{K} / \mathbf{C a}$ & $\mathrm{K}+\mathrm{Mg} / \mathrm{Ca}$ \\
\hline \multirow[t]{2}{*}{$\mathrm{t} \mathrm{ha}^{-1}$} & 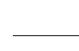 & 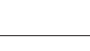 & $\mathrm{mg} \mathrm{kg}^{-1}$ & & & & & \\
\hline & \multicolumn{8}{|c|}{ 2003-2004 } \\
\hline 0 & 349 & 170 & 1502 & 23.0 & 53.0 & 15.1 & 65,3 & 67.6 \\
\hline 1.0 & $\begin{array}{l}349 \\
331\end{array}$ & 165 & 1458 & $\begin{array}{l}2.0 .0 \\
22.5\end{array}$ & 52.2 & $\begin{array}{l}10.1 \\
15.2\end{array}$ & 65.2 & 67.5 \\
\hline 2.0 & 339 & 159 & 1575 & 22.7 & 55.0 & 15.0 & 69.5 & 71.6 \\
\hline 3.0 & 357 & 180 & 1455 & 21.2 & 49.8 & 16.7 & 67.8 & 70.2 \\
\hline Effect ${ }^{(1)}$ & $\mathrm{ns}$ & $\mathrm{ns}$ & $\mathrm{ns}$ & $\mathrm{ns}$ & $\mathrm{ns}$ & $\mathrm{ns}$ & $\mathrm{ns}$ & $\mathrm{ns}$ \\
\hline CV (\%) & 8.4 & 10.6 & 9.8 & 9.8 & 11.7 & 13.3 & 10.0 & 9.7 \\
\hline 0 & 288 & 138 & 1313 & 39.2 & 54.5 & 7.4 & 33.8 & 35.1 \\
\hline 1.0 & 264 & 136 & 1267 & 37.2 & 52.0 & 7.1 & 34.0 & 35.4 \\
\hline 2.0 & 267 & 135 & 1298 & 40.2 & 55.5 & 6.7 & 32.6 & 33.9 \\
\hline 3.0 & 278 & 141 & 1318 & 37.7 & 53.7 & 7.4 & 35.3 & 36.8 \\
\hline Effect ${ }^{(1)}$ & $\mathrm{ns}$ & $\mathrm{ns}$ & $\mathrm{ns}$ & $\mathrm{ns}$ & $\mathrm{Ns}$ & $\mathrm{ns}$ & $\mathrm{ns}$ & $\mathrm{ns}$ \\
\hline \multirow[t]{2}{*}{ CV (\%) } & 5.6 & 4.4 & 2.3 & 11.0 & 6.0 & 12.5 & 11.9 & 11.9 \\
\hline & \multicolumn{8}{|c|}{ 2004-2005 } \\
\hline 0 & 334 & 138 & 1159 & 32.0 & 35.5 & 10.6 & 36.8 & 37.9 \\
\hline 1.0 & $\begin{array}{l}004 \\
327\end{array}$ & 142 & 1175 & 32.7 & 37.0 & 10.4 & 37.3 & 38.5 \\
\hline 2.0 & 313 & 171 & 1217 & 33.5 & 34.2 & 9.8 & 37.8 & 38.8 \\
\hline 3.0 & 320 & 151 & 1204 & 36.2 & 35.0 & 8.9 & 33.7 & 34.6 \\
\hline Effect ${ }^{(1)}$ & $\mathrm{ns}$ & $\mathrm{ns}$ & $\mathrm{ns}$ & $\mathrm{ns}$ & $\mathrm{ns}$ & $\mathrm{ns}$ & $\mathrm{ns}$ & $\mathrm{ns}$ \\
\hline \multirow{2}{*}{ CV (\%) } & 6.4 & 15.1 & 2.9 & 13.0 & 7.8 & 17.7 & 14.1 & 14.0 \\
\hline & \multicolumn{8}{|c|}{$2005-2006$} \\
\hline 0 & 316 & 172 & 1063 & 21.7 & 58.2 & 14.5 & 49.1 & 51.7 \\
\hline 1.0 & 338 & 170 & 1355 & 23.5 & 55.2 & 14.6 & 59.4 & 61.8 \\
\hline 2.0 & 340 & 169 & 1426 & 25.5 & 60.0 & 14.3 & 59.9 & 62.4 \\
\hline 3.0 & 335 & 168 & 1366 & 29.0 & 60.2 & 11.9 & 48.6 & 50.8 \\
\hline Effect $^{(1)}$ & ns & $\mathrm{ns}$ & $\mathrm{ns}$ & $\mathrm{ns}$ & $\mathrm{Ns}$ & ns & $\begin{array}{l}40.0 \\
\mathrm{~ns}\end{array}$ & $\mathrm{~ns}$ \\
\hline \multirow[t]{2}{*}{ CV (\%) } & 4.1 & 4.7 & 24.1 & 16.1 & 3.9 & 16.5 & 32.2 & 31.2 \\
\hline & \multicolumn{8}{|c|}{ 2006-2007 } \\
\hline 0 & 270 & 261 & 1339 & 24.7 & 41.2 & 11.0 & 54.1 & 55.8 \\
\hline 1.0 & 273 & 264 & 1280 & 24.7 & 43.0 & 11.0 & 51.8 & 53.5 \\
\hline 2.0 & 274 & 265 & 1338 & 23.0 & 39.7 & 12.0 & 58.3 & 60.1 \\
\hline 3.0 & 290 & 265 & 1312 & 23.0 & 44.5 & 12.6 & 57.2 & 59.2 \\
\hline Effect(1) & $\mathrm{ns}$ & $\mathrm{ns}$ & $\mathrm{ns}$ & $\mathrm{ns}$ & $\begin{array}{l}\mathrm{ns} \\
\mathrm{ns}\end{array}$ & $\mathrm{ns}$ & $\mathrm{ns}$ & $\begin{array}{l}59.2 \\
\mathrm{~ns}\end{array}$ \\
\hline \multirow[t]{2}{*}{ CV (\%) } & 4.5 & 5.9 & 9.5 & 9.7 & 6.4 & 9.7 & 13.6 & 13.4 \\
\hline & \multicolumn{8}{|c|}{$2008-2009$} \\
\hline 0 & 280 & 163 & 1077 & 54.5 & 39.5 & 5.5 & 19.7 & 20.7 \\
\hline 1.0 & 265 & 160 & 1108 & 50.5 & 40.2 & 5.2 & 22.5 & 23.2 \\
\hline 2.0 & 273 & 157 & 1064 & 54.0 & 39.2 & 5.0 & 20.0 & 20.5 \\
\hline 3.0 & 294 & 164 & 1131 & 54.5 & 42.5 & 5.5 & 20.7 & 21.7 \\
\hline Effect $^{(1)}$ & $\mathrm{ns}$ & $\mathrm{ns}$ & $\mathrm{ns}$ & $\mathrm{ns}$ & $\mathrm{ns}$ & $\mathrm{ns}$ & $\mathrm{ns}$ & $\mathrm{Ns}$ \\
\hline CV (\%) & 13.3 & 14.5 & 6.5 & 10.3 & 5.3 & 18.9 & 14.6 & 13.3 \\
\hline
\end{tabular}

(1) $\mathrm{L}^{*}$, ns: linear effect of gypsum application rate significant by polynomial regression $(\mathrm{p} \leq 0.05)$ or non significant (ns), respectively.

our study was very sensitive to Ca deficiency and the initial soil Ca content was much higher than that found in the cited studies, which may explain the different results.

\section{CONCLUSIONS}

1. Gypsum broadcast over the soil surface in eight consecutive years increased the Ca content in the soil profile, decreased $\mathrm{Mg}$ in the topsoil and had no effect on exchangeable $\mathrm{K}$ and $\mathrm{Al}$ values. As a consequence, it promoted a vertical movement of $\mathrm{Ca}$ in the profile but caused no $\mathrm{Mg}, \mathrm{K}$ and $\mathrm{Al}$ leaching from the layers of the apple roots.

2. Although Ca availability was increased in the soil profile, this was not sufficient to increase the
Ca concentration in leaves and fruits of an apple cultivar (Catarina) susceptible to Ca deficiency, even when grown on a limed soil. Thus, in Catarina apple orchards, more frequent $\mathrm{Ca}$ foliar sprays are essential to compensate for the inefficiency of the cultivar in accumulating $\mathrm{Ca}$ in fruits.

\section{LITERATURE CITED}

AMARANTE, C.V.T.; CHAVES, D.V. \& ERNANI, P.R. Composição mineral e severidade de bitter pit em maçãs 'Catarina'. R. Bras. Frutic., 28:51-54, 2006.

AMARANTE, C.V.T.; ERNANI, P.R.; STEFFENS, C.A. \& ARGENTA, L.C. O teor de cálcio na casca é indicativo da suscetibilidade ao "bitter pit" em maçãs 'Fuji'. R. Bras. Frutic., 33:180-186, 2011. 
BLUM, J.; CAIRES, E.F.; AYUB, R.A.; FONSECA, A.F.; SOZIM, M \& FAUATE, M. Soil chemical properties and grape yield as affected by gypsum application in Southern Brazil. Comm. Soil Sci. Plant Anal., 42:1434-1446, 2011.

CAIRES, E.F.; FONSECA, A.F.; MENDES, J.; CHUEIRI, W.A. \& MADRUGA, E.F. Produção de milho, trigo e soja em função das alterações das características químicas do solo pela aplicação de calcário e gesso na superfície, em sistema de plantio direto. R. Bras. Ci. Solo, 23:315-327, 1999.

CAIRES, E.F.; BLUM, J.; BARTH, G.; GARBUIO, F.J. \& KUSMAN, M.T. Alterações químicas do solo e resposta da soja ao calcário e gesso aplicados na implantação do sistema plantio direto. R. Bras. Ci. Solo, 27:275-286, 2003.

CAIRES, E.F.; CHURKA, S.; GARBUIO, F.J.; FERRARI, R.A. \& MORGANO, M.A. Soybean yield and quality as a function of lime and gypsum applications. Sci. Agric., 63:370-379, 2006.

CAMILO, A.P. \& DENARDI, F. Cultivares: Descrição e comportamento no sul do Brasil. In: EPAGRI. A cultura da macieira. Florianópolis, 2002. p.113-168.

CARVALHO, M.C.S. \& RAIJ, B.van. Calcium sulphate, phosphogypsum and calcium carbonate in the amelioration of acid subsoils for root growth. Plant Soil, 192:32-48, 1997.

COMISSÃO DE QUÍMICA E FERTILIDADE DO SOLO CQFSRS/SC. Manual de adubação e de calagem para os estados do Rio Grande do Sul e de Santa Catarina. 10.ed. Porto Alegre, Sociedade Brasileira de Ciência do Solo, 2004. 400p.

EMPRESA BRASILEIRA DE PESQUISA AGROPECUÁRIA EMBRAPA. Centro Nacional de Pesquisa em Solos (CNPS). Manual de Métodos de Análise de Solo. ed. Rio de Janeiro, 1997. 212p.

ERNANI, P.R.; RIBEIRO, M.F.S. \& BAYER, C. Modificações químicas em solos ácidos ocasionadas pelo método de aplicação de corretivos da acidez e de gesso agrícola. Sci. Agric., 58:825-831, 2001.

ERNANI, P.R. Alterações em algumas características químicas da camada arável do solo pela aplicação de gesso agrícola sobre a superfície de campos nativos. R. Bras. Ci. Solo, 10:241-245, 1986.

ERNANI, P.R. \& BARBER, S.A. Composição da solução do solo e lixiviação de cátions afetados pela aplicação de cloreto e sulfato de cálcio em um solo Ácido. R. Bras. Ci. Solo, 17:41-46, 1993.

ERNANI, P.R.; MIQUELUTTI, D.; FONTOURA, S.M.V.; KAMINSKI, J. \& ALMEIDA, J.A. Downward movement of soil cations in highly weathered soils caused by gypsum application. Comm. Soil Sci. Plant Anal., 37:571-586, 2006.

ERNANI, P.R.; DIAS, J.; AMARANTE, C.V.T.; RIBEIRO, D.C. \& ROGERI, D.A. Preharvest calcium sprays were not always needed to improve fruit quality of 'Gala' apples in Brazil. R. Bras. Frutic., 30:892-896, 2008.
FREIRE, C.J.S. Manual de métodos de análise de tecido vegetal, solo e calcário. Pelotas, Embrapa/CPACT, 1998. 208p.

MALAVOLTA, E.; VITTI, G.C. \& OLIVEIRA, S.A. Nutritional status of nutrition of plants. 2.ed. Piracicaba, Potafos, 1997.

NAVA, G. \& DECHEN, A.R. Long-term annual fertilization with nitrogen and potassium affect yield and mineral composition of Fuji apple. Sci. Agric., 66:377-385, 2009.

PAVAN, M.A. Influence of calcium and magnesium salts on acid soil chemistry and calcium nutrition of apple. Soil Sci. Soc. Am. J., 51:1520-1530, 1987.

PAVAN, M.A.; BINGHAM, F.T. \& PRATT, P.F. Toxicity of aluminum to coffee in Ultisols and Oxisols amended with $\mathrm{CaCO}_{3}$, $\mathrm{MgCO}_{3}$ and $\mathrm{CaSO}_{4}$. Soil Sci. Soc. Am. J., 46:201-1207, 1982.

PAVAN, M.A.; BINGHAM, F.T. \& PRATT, P.F. Redistribution of exchangeable calcium, magnesium, and aluminum following lime or gypsum applications to a Brazilian Oxisol. Sci. Soc. Am. J., 48:33-38, 1984.

RITCHEY, K.D.; SILVA, J.E. \& COSTA, U.F. Calcium deficiency in clay B horizons of savanna Oxisols. Soil Sci., 133:378$382,1982$.

ROSOLEM, C.A. \& MACHADO, J.R. Efeitos da calagem e gessagem na produção de algodão e na lixiviação de bases em dois latossolos. R. Bras. Ci. Solo, 8:103-109, 1984.

SUMNER, M.E.; SHAHANDEH, H.; BOUTON, J. \& HAMMEL, J. Amelioration of an acid soil profile through deep liming and surface application of gypsum. Soil Sci. Soc. Am. J., 50:1254-1278, 1986.

SUZUKI, A.; BASSO, C. \& WILMS, F.W. O uso de gesso como fonte complementar de cálcio em macieira. In: SEMINÁRIO SOBRE O USO DE GESSO NA AGRICULTURA, 2., Uberaba, 1992. Anais... Uberaba, IBRAFÓS, 1992. p.224-240.

SUZUKI, A. \& BASSO, C. Fertilidade do solo e nutrição da macieira. In: EPAGRI. Manual da cultura da macieira. Florianópolis, 2002. p.341-382.

SYED-OMAR, S.R. \& SUMNER, M.E. Effect of gypsum on soil potassium and magnesium status and growth of alfalfa. Comm. Soil Sci. Plant Anal., 22:2017-2028, 1991.

TAIZ, Z. \& ZEIGER, E. Fisiologia vegetal. 4.ed. Porto Alegre, Artmed, 2008. 719p.

ZAMBROSI, F.C.B.; ALLEONI, L.R.F. \& CAIRES, E.F. Nutrient concentration in soil water extracts and soybean nutrition in response to lime and gypsum applications to an acid Oxisol under no-till system. Nutr. Cycl. Agroecosyst., 79:169-179, 2007.

WEBSTER, D. Response of cortland apple trees and the underlying soil to gypsum. Acta Hortic., 274:515-516, 1990. 